\title{
SWOT Analysis of Dairy Sector Development in Haryana
}

\author{
Lalita Garg', Kamal Kumar $^{2 *}$ and Rishi Kumar Singh ${ }^{3}$ \\ ${ }^{1}$ Division of Livestock Products Technology, ${ }^{2}$ Division of Veterinary Extension Education, \\ ICAR-Indian Veterinary Research Institute, Izatnagar, Bareilly, U.P., India \\ ${ }^{3}$ Department of Agricultural Extension, ANDUAT, Kumarganj, Ayodhya, U.P., India \\ *Corresponding author
}

\section{A B S T R A C T}

\begin{tabular}{|l|}
\hline Ke y w or d s \\
$\begin{array}{l}\text { SWOT Analysis, } \\
\text { Dairy Ssector, } \\
\text { Livestock sector }\end{array}$ \\
\hline Article Info \\
\hline $\begin{array}{l}\text { Accepted: } \\
\text { 22 January } 2021 \\
\text { Available Online: } \\
\text { 10 February } 2021\end{array}$ \\
\hline
\end{tabular}

The livestock sector is one of the fastest growing segments of the agricultural economy in India. Over the period, the contribution of livestock segment in the agriculture sector has been showing steady improvement that attributes to its importance in the Indian economy. Being the home tract of Hariana breed of cows and Murrah breed of buffaloes, from the ancient times the state has a special place in livestock sector on the map of India. The government of Haryana took up various initiatives for dairy development in the state. So the present study was designed to analyze the strength, weaknesses, opportunities, and threats in dairy sector development in Haryana. The data for the study was collected from secondary sources. Based on the data analysis the strengths, weaknesses, opportunity and threats of the dairy sector development in Haryana were identified. The finding of the study would be very helpful for all the concerned stakeholders who are working for the dairy development in the state.

\section{Introduction}

Livestock is an integral component of farming system in India and contribute immense support to the overall development of agriculture sector in the country. It plays a vital role in the life of farmers. Dairy farming is essential not only as a source of income but also as a reservoir of protein, supplementary nutrition, fertilizer, fuel, and a store of wealth for millions of households across the country. Over the period, the contribution of livestock segment in the Agriculture sector has been showing steady improvement that attributes to its importance in the Indian economy. The state departments of animal husbandry are also considered as indispensable part of the whole system in achieving the progress towards the sector.

The livestock sector is one of the fastest growing segments of the agricultural economy in India. It contributes nearly 28.63 percent of the total value of agriculture GDP and accounts for about 4.2 percent of the total GDP. The overall growth of livestock sector shows increasing trends and is around 8.24 per cent and this has been achieved despite the fact that the investment in this sector was not substantial. During 2019-20, livestock 
sector contributed 198.4 million tonnes of milk, 63.02 billion eggs, 42.99 million $\mathrm{kg}$ wool, and 4.83 million tonnes of meat. India ranks first in the world in milk production, which went up from 17 million tonnes in 1950-51 to 198.4 million tonnes in 2019-20. The per capita availability of milk has also increased from 112 grams per day in 1968-69 to 407 grams in 2019-20. The average yield per animal per day for exotic/crossbred is $7.95 \mathrm{~kg}$ per day and for indigenous/nondescript is $3.01 \mathrm{~kg}$ per day. The milk production from exotic/ crossbred cattle has increased by 8.7 percent and for indigenous/ non-descript cattle it has increased by 5.7 percent compared to previous year. The milk production from buffalo also increased by 6.4 percent in comparison to previous year.

To improve the milk production, the central and the state governments implemented various development programmes. Being the home tract of Hariana breed of cows and Murrah breed of buffaloes, from the ancient times Haryana has a special place in livestock sector on the map of India.

The state government took up various initiatives for dairy development. Because of these programmes Haryana has $2^{\text {nd }}$ highest per capita milk availability in the country and thirds highest annual growth rate in the milk production. So the present study was designed to analyze the strength, weaknesses, opportunities, and threats in dairy sector development in Haryana.

\section{Materials and Methods}

The data for the study was collected from secondary sources like annual reports of state department of animal husbandry Haryana, Animal husbandry statistics report of government of India (GoI) and $20^{\text {th }}$ livestock census by the department of animal husbandry, GoI. The data was subjected to appropriate statistical analysis and presentation.

\section{Results and Discussion}

\section{Dairy animals' population and production scenario in India}

The major dairy animals of the country are buffalo, cattle and goat. As per the provisional estimates of $20^{\text {th }}$ livestock census the total cattle, buffalo and goat population in the country is 192.4 million, 109.85 million and 148 million respectively. Out of 192.4 million cattle 145.11 were female cattle and milch population is 74.17 million whereas only 43.9 million cattle are in milk.

In case of buffaloes 100 million are female out of which 51.16 million are milch whereas only 38.16 million are in milk. The population trends of dairy animals, between $19^{\text {th }}$ and $20^{\text {th }}$ livestock census are shown in the Figure 1 and Figure 2.

As shown in Figure 3 the largest contribution in the milk production of the country is of buffalo (49\%) followed by cow (48\%) and goats $(3 \%)$. The average milk yield of the cross bred/ exotic cattle is $7.95 \mathrm{~kg} / \mathrm{animal} / \mathrm{day}$ whereas for non-descript/ indigenous cattle is $3.01 \mathrm{~kg} / \mathrm{animal} /$ day. As shown in Figure 4, the contribution of livestock sector to total GVA is on increasing trends.

\section{Livestock sector in Haryana}

As a consequence of rapid structural transition of the State's economy over the years, the contribution of the Agriculture and Allied Sectors at constant (2011-12) prices went down to only 16.6 percent of the GSVA during the year 2019-20. The economic growth of the State has become more dependent on the growth in Industry and Services Sectors during the past few years. 
However, recent experiences suggests that high GSVA growth without sustained and rapid agricultural growth is likely to accelerate inflation in the State jeopardizing the larger growth process. Therefore, the growth of Agriculture and Allied Sectors continue to be a critical factor in the overall performance of the State's economy. Agriculture and Allied Sectors consist of agriculture, forestry \& logging and fishing sub-sectors. Agriculture including crop husbandry and dairy farming is the main component contributing about 93 percent in GSVA of Agriculture and Allied Sectors.

The estimates indicate that the growth rate has increased from 3.8 percent in 2015-16 to 7.9 percent in $2016-17$ but it fell to 6.1 percent and 5.3 percent in 2017-18 and 2018-19, respectively. As per the Advance Estimates for 2019-20, the GSVA from this sector has been recorded as $83,174.62$ crore with the growth of 4.5 percent. The GSVA from Agriculture Sector including crops and livestock has been estimated as 78,677.16 crore with the growth of 4.5 percent.

\section{Dairy animals' population in the state}

The major dairy animals of the state are buffalo, cattle and goat. As per the $20^{\text {th }}$ livestock census, the total livestock population of the State is 71.26 lakhs, while population of the dairy animals is 66.44 lakhs.

The buffalo population of 43.76 lakhs accounts for 61.40 percent of the total livestock in the State. Buffalo comprises 69.37 percent of the total bovines (63.08 lakhs) reared in the State. As far as cattle is concerned, it comprises 30.62 percent of the total bovine population and 27.11 percent of the total livestock population. The trends of the dairy bovine population are shown in Figure 5 and Figure 6.

\section{Dairy production scenario in the state}

Haryana is rightfully known as the milk pail of India. It has earned the distinction of being home tract of the World famous Murrah buffaloes and Haryana cows. The estimated milk production, which was 19.50 lakh tonnes during 1979-80, has increased to 107.26 lakh tonnes during 2018-19 and estimated production for the year 2019-20 is 117 lakh tonnes. The contribution of Indigenous buffalo, non-descript buffalo and goat in the total milk of the state is 75.23 lakh tonne, 11.59 lakh tonnes and 0.5 lakh tonnes, respectively. The productivity of the indigenous buffalo, non-descript buffalo and goat were $9.34,7.88$, and $1.01 \mathrm{~kg} /$ animal/day, respectively.

As far as cattle is concerned the contribution in milk production of the state is 1.8 lakh tonnes, 13.5 lakh tonne, 3.3 lakh tonne and 1.17 tonne by the exotic, crossbred, indigenous and non-descript cattle, respectively. The productivity of the exotic, crossbred, indigenous and non-descript cattle is $11.09,8.69,6.15$ and $5.3 \mathrm{~kg} / \mathrm{animal} /$ day, respectively.

The annual growth rate of milk production in Haryana is 9.3 percent which is third highest in the country. The state contributes 5.7 percent of the total milk production of the country. The trends in milk production over the various five year plans are shown in Figure 7.

\section{Food-cum-nutritional security through dairy sector in Haryana}

The per capita availability of milk per day has increased from $440 \mathrm{gm}$ during in 1979-80 to 1087 gm during 2018-19. As per the Indian Council of Medical research (ICMR) recommendation, the per capita requirement of milk should be 300 grams per day. The 
state has $2^{\text {nd }}$ highest per capita milk productivity in the country. The trends in per capita milk availability in various five year plans are shown in Figure 8.

Fig.1 Share of female, milch and in-milk buffaloes in total population of buffalo in India

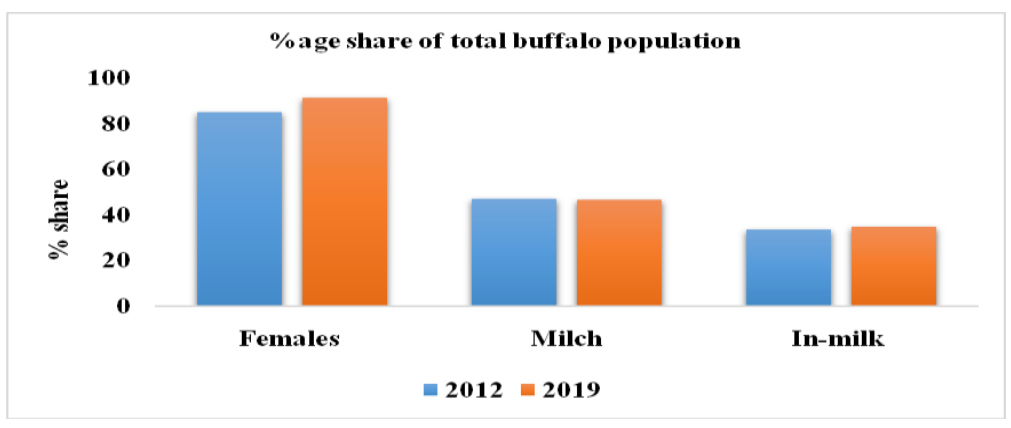

Fig.2 Share of female, milch and in-milk cattle in total population of cattle in India

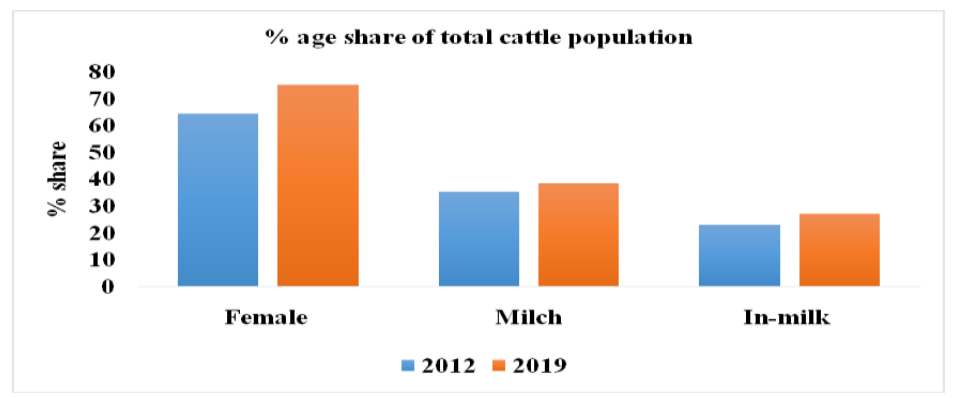

Fig.3 Share of dairy species in total milk production of India

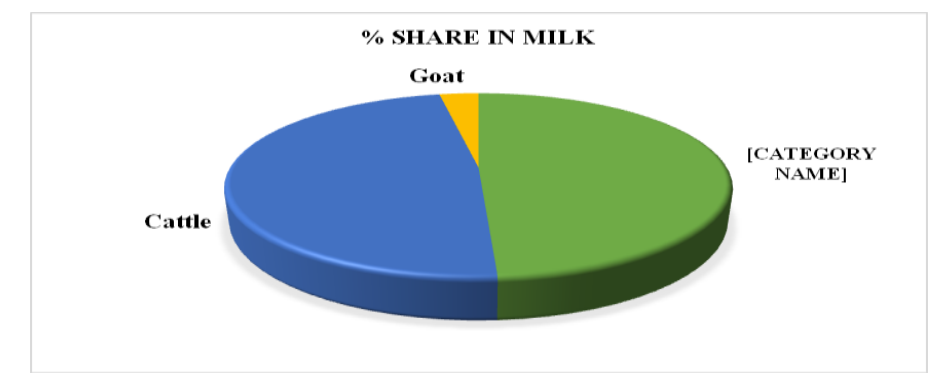

Fig.4 Trends in the share of livestock and crop sector in total GVA

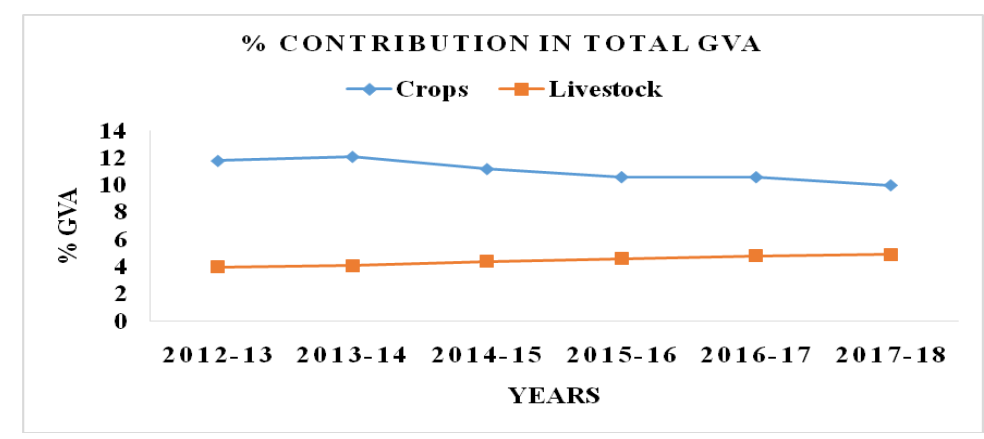


Fig.5 Change in milch bovine population in Haryana between $19^{\text {th }}$ and $20^{\text {th }}$ livestock census

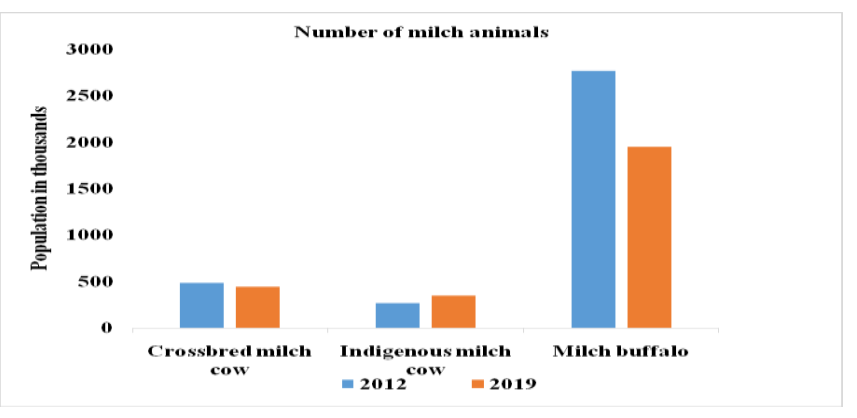

Fig.6 Change in bovine population from $19^{\text {th }}$ to $20^{\text {th }}$ livestock census in Haryana

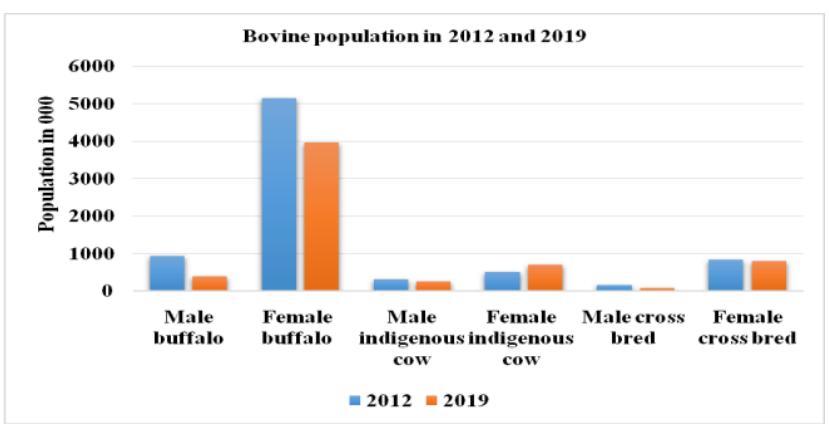

Fig.7 Trends in dairy production in various five year plans in Haryana

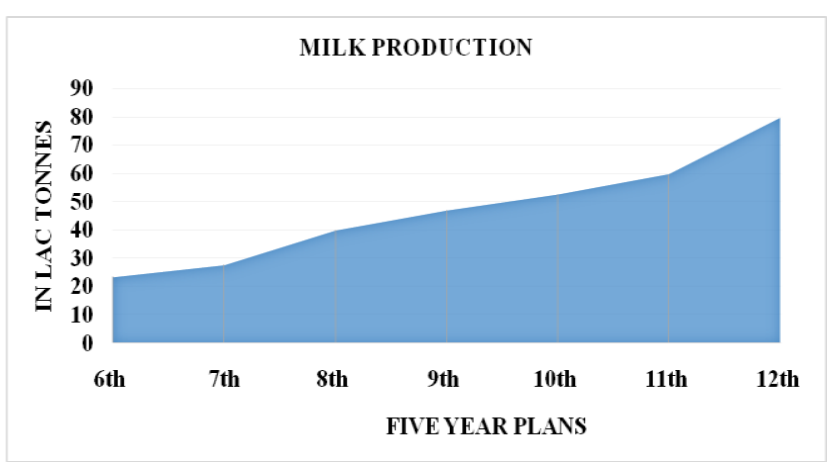

Fig.8 Trends in per capita milk availability per day in various five year plans in Haryana

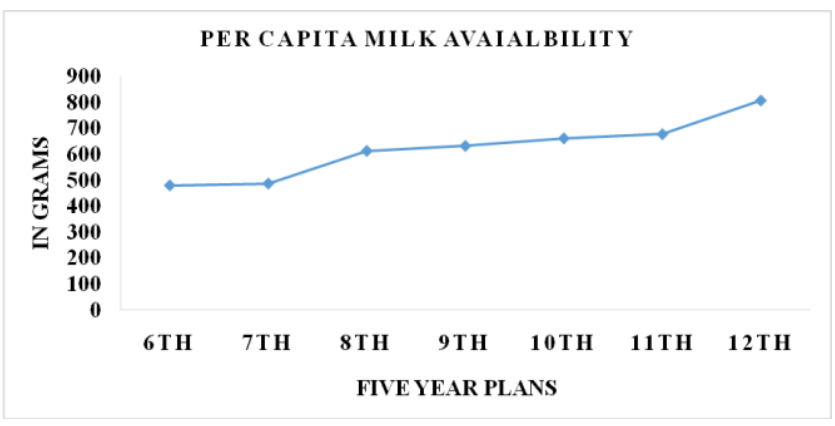


Fig.9 Fodder availability trends in Haryana

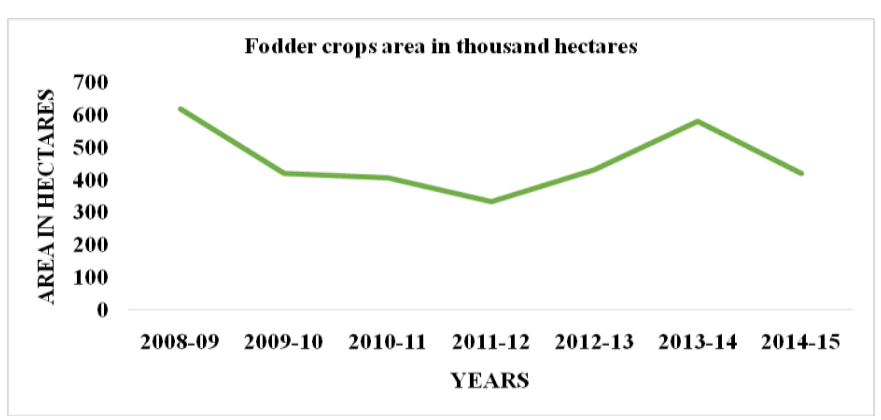

Fig.10 Pasture and grazing land in Haryana

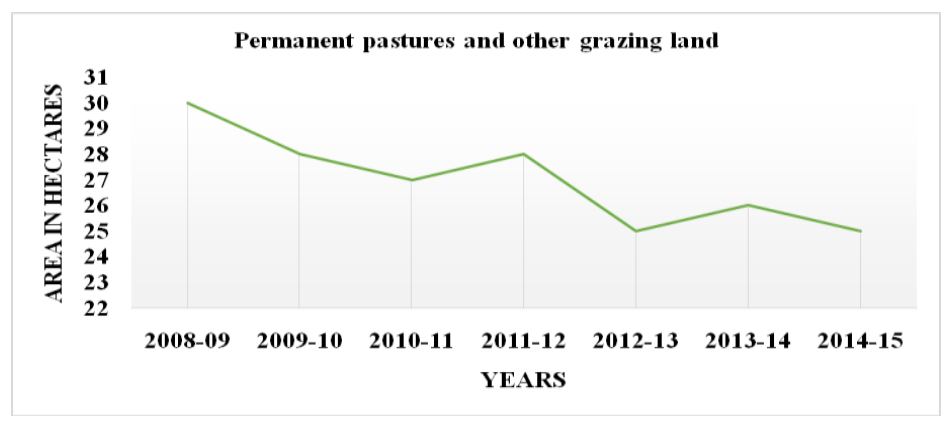

Veterinary infrastructure and human resources in the state

The state possesses the 1018 government veterinary hospitals, 1817 government veterinary dispensaries, 10 semen storage bank, and 3 production semen bank. There are 22 animal disease diagnostic labs in the state. But the number of veterinarian in the state is very less. There is one veterinarian per 8637 livestock population in Haryana. The general norm is to have at least one veterinary doctor for every 5,000 animals.

\section{Dairy training center and experiment laboratory}

To make the dairying profitable for the milk producers, the state government established dairy training center in Gurugram and Karnal to provide 11 days training on scientific dairying to educated and semi-educated youths. Training programmes are also being organized at block and district level. State veterinary university also organizes training camps in the university campus as well as at village level.

Milk and milk products are the choice foods in Haryana. Therefore it is quintessential to ensure availability of clean, tasty, and microbes free dairy products to the consumers. Milk testing laboratories are established by the state government with the objective of ensuring quality milk production to enhance consumer satisfaction, Odiagnosis of sub-clinical and clinical mastitis and also to maintain quality standards of the milk supply by private and cooperative sector.

\section{Disease outbreaks}

As per government reports no Foot and Mouth disease outbreak is reported in the state during the year 2018-19. But the cases of zoonotic diseases are reported in the state such as Brucellosis and Tuberculosis. 


\section{Feed and fodder resources}

As shown in Figure 9 and 10, over the years area under fodder production as well as grazing is on decreasing trends. The state government had fodder seed bank to supply the fodder to the livestock farmers at nominal rates.

\section{Other dairy development initiative}

The state government is running a mini dairy unit scheme to ensure employment for the unemployed youths. To insured the animal and transfer the risk of the dairy farmers 'Pandit Deen Dyal Upadhyay Livestock Insurance Scheme' is being run by the state government. To produce progeny with high genetic merit, the availability of the sex sorted semen technology at all GVHs and GVDs is being ensured by the state government.

\section{SWOT analysis of dairy sector in Haryana}

\section{Strength}

Strong veterinary services infrastructure Government policies towards dairy sector Innovative technologies

Source of regular income Equitable distribution of livestock Availability of superior quality germplasm Home to best buffalo breed of the world No FMD outbreak in the year 2018-19

\section{Weakness}

Lowper animal productivity

Frequent disease outbreaks

More input cost due to non-scientific practices

Small herd size

Decreasing number of milch animals

\section{Opportunities}

Increasing demand for milk
Value addition

Silent heat in buffaloes

Higher population of unproductive cows and buffaloes

Prolonged inter-calving and dry period under field conditions

Lack of organized market for dairy products Urbanization

Increasing population

Raise in per capita income

Changing food habits

Export potential

Less procurement in the organized sector

\section{Threats}

Negative consequences of cross breeding programmes

Feed and fodder scarcity

Free trade agreements

Lack of competitiveness in the international market

Vegan and vegetarian debates

Delayed payments by the cooperatives

Low private sector investment

Low milk prices

Human resources for veterinary services

Poor livestock extension

In conclusion and implications

A proper milk pricing policy should be chalked out, so that farmers can get remunerative prices

Use of feed supplements, utilization of by products and Azolla feeding can be the alternate source to counter the scarcity of feed and fodder

Fodder seed bank has to be established at regional and village level for uninterrupted supply of fodder seeds

Awareness among the dairy farmers about various dairy development programmes

Training of farmers about the importance of balanced feeding, it can reduce their input cost and they can reap more profit 
Structural transformation of the cooperative sector to make their working more efficient and transparent

Incentive should be given to the progressive dairy farmers

Creation of market and increased procurement by the organized sector

Creation of human resources for veterinary services

\section{References}

Government of Haryana. 2020. Animal Husbandry Statistics 201819http://pashudhanharyana.gov.in/sites/ default/files/documents/Statistics/Annua 1\%20Admin\%20Report\%20Year\%2020 18-19_opt.pdf accessed on 9 February, 2021

Government of India. 2019. Basic Animal Husbandry Statistics 2019 http://dahd.nic.in/circulars/basicanimal-husbandry-statistics2019accessed on 30January 2021

Government of India.2021. Economic Survey 2020- 21https://www.indiabudget.gov.in/econ omicsurvey/doc/vol2chapter/echap07_v ol2.pdf accessed on 10 February, 2021

$20^{\text {th }} \quad$ livestock census. 2019 https://vikaspedia.in/agriculture/agridirectory/reports-and-policybriefs/20th-livestock census\#: :text=Total\%20Bovine\%20po pulation\%20(Cattle\%2C\%20Buffalo, of $\% 200.8 \% 20 \% 25 \% 20$ over\%20previous $\%$ 20Censusaccessed on 1February 2021

Government of India. 2020. National Dairy Development Board Annual Report 2018-

19.https://www.nddb.coop/sites/default/ files/NDDB-AR-2019-ENGLISH24022020.pdf accessed on 6February 2021

Indian express. 2014. 30 crore cattle and rising, but where are the country's vets?https://indianexpress.com/article/in dia/india-others/30-crore-cattle-andrising-but-where-are-the-countrys-vets/ accessed on 12 February 2021

\section{How to cite this article:}

Lalita Garg, Kamal Kumar and Rishi Kumar Singh. 2021. SWOT Analysis of Dairy Sector Development in Haryana. Int.J.Curr.Microbiol.App.Sci. 10(02): 3070-3077. doi: https://doi.org/10.20546/ijcmas.2021.1002.335 